\title{
EDITORIAL
}

\section{The Global Anti-Base Erosion Proposal (GloBE) in Pillar II}

\section{INTRODUCTION}

The Global Anti-Base Erosion Proposal (GloBE) in the OECD Public Consultation Document ${ }^{1}$ is offered as an answer to the 'Tax Challenges Arising from the Digitalization of the Economy'. It is a result of the Programme of Work on Pillar Two, ${ }^{2}$ and it proposes the development of a coordinated set of rules to address profit shifting within company groups to jurisdictions where they are subject to no or very low taxation.

In order to avoid such profit shifting, the GloBE Proposal is composed of four interrelated and complementary measures, two of which are applicable by the residence and the other two by the source jurisdiction.

The measures - the 'four component parts' - of the proposal are described as follows:

a) An income inclusion rule that would tax the income of a foreign branch or a controlled entity if that income was subject to tax at an effective rate that is below a minimum rate;

b) an undertaxed payments rule that would operate by way of a denial of a deduction or imposition of source-based taxation (including withholding tax) for a payment to a related party if that payment was not subject to tax at or above a minimum rate;

c) a switch-over rule to be introduced into tax treaties that would permit a residence jurisdiction to switch from an exemption to a credit method where the profits attributable to a permanent establishment (PE) or derived from immovable property (which is not part of a PE) are subject to an effective rate below the minimum rate; and d) a subject to tax rule that would complement the undertaxed payment rule by subjecting a payment to withholding or other taxes at source and adjusting eligibility for treaty benefits on certain items of income where the payment is not subject to tax at a minimum rate. ${ }^{3}$

The income inclusion and the switch-over rules are to be applied by the residence jurisdiction whereas the undertaxed payments and the subject to tax rules are to be applied by the source jurisdiction.

All four measures require determination of a 'minimum tax rate' to be decided internationally (in the Inclusive Framework), i.e. the four measures are applicable by reference to a consensual minimum effective tax rate and not by reference to domestic tax rates. Each of the four measures are meant to achieve a minimum effective tax rate in group taxation.

The GloBE Proposal specifically requests feedback on three technical design aspects:

a) the use of financial accounts as a starting point for determining the tax base under the GloBE proposal as well as different mechanisms to address timing differences;

b) the extent to which an Multinational Enterprise (MNE) can combine high-tax and low-tax income from different sources taking into account the relevant taxes on such income in determining the effective (blended) tax rate on such income; and

c) stakeholders' experience with, and views on, carveouts and thresholds that may be considered as part of the GloBE proposal. ${ }^{4}$

\section{Notes}

OECD, Global Anti-Base Erosion Proposal (GloBE) Pillar Two, Public Consultation Document, 8 Nov. 2019-2 Dec. 2019 (OECD Publishing Nov. 2019 ), https://www.oecd. org/tax/beps/public-consultation-document-global-anti-base-erosion-proposal-pillar-two.pdf.pdf (accessed 1 Dec. 2019) (hereafter: OECD, Public Consultation Document Pillar 2).

2 OECD, Programme of Work to Develop a Consensus Solution to the Tax Challenges Arising from the Digitalisation of the Economy, OECD/G20 Inclusive Framework on BEPS (OECD Publishing May 2019), https://www.oecd.org/tax/beps/programme-of-work-to-develop-a-consensus-solution-to-the-tax-challenges-arising-from-the-digitalisation-of-theeconomy.pdf (accessed 1 Dec, 2019) (hereafter: OECD, Programme of Work); and OECD, Addressing the Tax Challenges of the Digitalisation of the Economy - Policy Note, OECD/G20 Inclusive Framework on BEPS, (OECD Publishing, Jan. 2019), https://www.oecd.org/tax/beps/policy-note-beps-inclusive-framework-addressing-tax-challengesdigitalisation.pdf (accessed 1 Dec. 2019) (hereafter: OECD, Policy Note).

OECD, Public Consultation Document Pillar 2, supra n. 1, at 6 .

4 OECD, Public Consultation Document Pillar 2, supra n.1, at 3 . 
It is also mentioned that technical design aspects depend on previous political options and that the proposals have been prepared by the Secretariat and do not represent the consensus views of the Inclusive Framework, the Committee on Fiscal Affairs (CFA), or their subsidiary bodies. ${ }^{5}$

The analysis of the GloBE in the following paragraphs will also address the three technical design aspects but is not limited to them.

\section{JUSTIFICATION OF PILLAR TWO}

As mentioned above, Pillar Two is meant to 'address ongoing risks from structures that allow MNEs to shift profits to jurisdictions where they are subject to no or very low taxation'. 6 Therefore, it is justified as being complementary to the Base Erosion and Profit Shifting (BEPS) Project. ${ }^{7}$ Apparently, elimination of disparities and introduction of anti-avoidance rules in the framework of the project do not solve all profit shifting issues.

The taxing right granted to the market state in respect of highly digitalized business, proposed by Pillar One ${ }^{8}$ and on the basis of a residual deemed profit method (presumptive method, residual to taxation according to the arm's length standard), is also not sufficient as it does not guarantee that there will be enough taxation in the market State. ${ }^{9}$ Thus, both the BEPS Project and Pillar One afford opportunities for aggressive tax planning and profit shifting targeting low tax jurisdictions.

Pillar Two proposes the coordination of rates, a topic that has been raised in the OECD 1998 Report on Harmful Tax Practices, ${ }^{10}$ according to which harmful regimes would be identified according to the following four criteria:

No or nominal taxes in the event of tax havens and no or low effective tax rates on the relevant income in the case of preferential regimes; lack of effective exchange of information; lack of transparency; and no substantial activities in the case of tax havens and ring fencing in the case of preferential regimes. ${ }^{11}$

The implicit reference to minimum effective rates in the 1998 Report was abandoned in the 2001 Report.
First, the 2001 OECD Report recognized advantages in the reduction of rates that had been accompanied by the broadening of tax bases:

1. The more open and competitive environment of the last decades has had many positive effects on tax systems, including the reduction of tax rates and broadening of tax bases which have characterized tax reforms over the last fifteen years. In part these developments can be seen as a result of competitive forces which have encouraged countries to make their tax systems more attractive to investors. In addition to lowering overall tax rates, a competitive environment can promote greater efficiency in government expenditure programs.

2. However, some tax and related practices are anticompetitive and can undercut the gains that tax competition generates. This can occur when governments introduce practices designed to encourage noncompliance with the tax laws of other countries. ${ }^{12}$

Then, it attributed a different value to the afore-mentioned 'no or nominal taxes' factor:

The first factor - no or nominal taxes in the case of tax havens and no or low effective tax rates on the relevant income in the case of preferential regimes - is a gateway criterion to determine those situations in which an analysis of the other criteria is necessary" 13

28 ... the Committee has decided that commitments will be sought only with respect to the transparency and effective exchange of information criteria to determine which jurisdictions are considered as uncooperative tax havens. In applying the transparency and exchange of information criteria many factors are relevant, including a relaxed regulatory framework, which reduces transparency and makes it less likely that the information needed for effective exchange of information will be available. The Forum will continue to examine all factors affecting the ability of a jurisdiction to engage in effective exchange of information. ${ }^{14}$

\section{Notes}

5 OECD, Public Consultation Document Pillar 2, supra n. 1, at 3.

OECD, Public Consultation Document Pillar 2, supra n. 1, at 3.

OECD, Action Plan on Base Erosion and Profit Shifting (OECD Publishing July 2013), https://www.oecd.org/ctp/BEPSActionPlan.pdf (accessed 1 Dec. 2019).

8 OECD, Secretariat Proposal for a 'Unified Approach' Under Pillar One, Public Consultation Document 9 Oct. 2019-12 Nov. 2019 (OECD Publishing Oct. 2019), https://www. oecd.org/tax/beps/public-consultation-document-secretariat-proposal-unified-approach-pillar-one.pdf (accessed 1 Dec. 2019).

9 A. P. Dourado, The OECD Unified Approach and The New International Tax System: A Half-Way Solution, 48 Intertax 1 (2020).

10 OECD, Harmful Tax Competition, An Emerging Global Issue (OECD Publishing 1998), https://read.oecd-ilibrary.org/taxation/harmful-tax-competition_9789264162945en\#page1 (accessed 1 Dec. 2019).

11 OECD, Harmful Tax Competition, An Emerging Global Issue, supra n. 10, at 23.

12 OECD, The OECD's Project on Harmful Tax Practices: The 2001 Progress Report 4 (OECD Publishing 2001), https://www.oecd.org/ctp/harmful/2664438.pdf (accessed 1 Dec. 2019).

13 Ibid., at 5.

14 Ibid., at 4 
At the time, primacy was given to combat harmful tax jurisdictions that were defined as uncooperative jurisdictions. The fight against harmful tax jurisdictions has received new strength since 2009 as an outcome of the 2008 financial crisis. ${ }^{15}$ The BEPS Project appeared autonomously in $2013^{16}$ to target aggressive tax planning but could be interpreted as being complementary to the international standard on the exchange of information.

There is no public evidence that the exchange of information implemented since then has been effective for eliminating harmful tax competition, and it might have even increased (non-harmful) tax competition. The novelty in Pillar Two is that it aims to combat tax competition and not only base erosion and profit shifting. Otherwise stated, Pillar Two is justified because base erosion and profit shifting cannot be combatted in a world of tax competition.

In the proposal, both cooperative and non-cooperative jurisdictions are targeted. However, they may still be subject to different rates as the minimum tax rate towards investment in uncooperative jurisdictions (harmful tax regimes) may be submitted to a higher tax rate than the general minimum tax rate: 'at the higher of the minimum rate or the full domestic rate'. ${ }^{17}$

The time is over when it seemed enough to only obtain information about cross-border transactions in order to tax properly.

\section{OBjective scope of PILLAR tWo}

The activities covered by Pillar Two are not yet defined, but some assertions therein suggest a broad objective scope that is beyond highly digitalized activities. According to the proposal, the:

GloBE ... is expected to affect the behavior of taxpayers and jurisdictions. It posits that global action is needed to stop a harmful race to the bottom on corporate taxes, which risks shifting the burden of taxes onto less mobile bases and may pose a particular risk for developing countries with small economies. ${ }^{18}$

Restricting the application of the minimum tax rate to highly digitalized activities would be consistent with Pillar One. However, it ring fences the economy and does not achieve the purpose of reducing tax competition and profit shifting. On the contrary, ring fencing fosters aggressive tax planning that is excluded and in grey areas, and it is distortive by promoting business in those sectors that are not encompassed within the minimum tax rate.

\section{Subjective scope ANd CARVe-OUts}

The meaning of Group for the purposes of applying the minimum tax rate is not yet defined. Its definition - for example, limiting the application of the minimum tax rate to groups reaching the threshold of EUR 750 million of turnover - as well as carve-outs of certain economic sectors will also ring fence the economy and bring complexity and distortions into domestic law and tax treaties, again fostering tax planning. It could be argued that the determination of a threshold limits the scope of the application of the minimum tax rate to fewer taxpayers and, in this aspect, reduces complexity. However, this is an apparent simplicity as it is not tax neutral.

Carve-outs will be in accordance with the purpose of taxing highly-digitalized businesses and, if approved, they should be in line with Pillar One for the sake of consistency. However, the purpose of reducing tax competition and aggressive tax planning will not be achieved.

In this context, the reference in the proposal to inefficient tax incentives in developing countries is, at the least, awkward since their tax incentives are not yet focused on the digital economy. Carve-outs will probably be approved in the interest of the OECD economies for their most fragile economic sectors such as agriculture and some brick-and mortar industries as well as those they want to incentivize such as research and development activities.

\section{The USE OF FinANCIAL ACCOUNTS}

Determining the minimum tax rate for the purposes of applying the four above-mentioned components of the proposal depends on the fulfilment of several conditions. First, to achieve a level playing field among resident and source jurisdictions requires determination of the effective tax rate following an international standard; this would subsequently require harmonization of tax bases.

The Programme of Work had critically analysed the determination of the tax base by reference to national CFC rules or, in the absence of the former, to the domestic Corporate Income Tax rules of the shareholder's jurisdiction. ${ }^{19}$ This would be a complex solution, and it

\section{Notes}

15 OECD, Tax Co-operation 2009: Towards a Level Playing Field - 2009 Assessment by the Global Forum on Transparency and Exchange of Information (OECD Publishing Sept. 2009). See also A. P. Dourado, International Standards, Base Erosion and Developing Countries, in Tax Design Issues Worldwide 179 et seq. (G. M. M. Michielse \& V. Thuronyi eds, Kluwer 2015).

16 As a result of the G20, Leaders Declaration, Los Cabos Summit, 48 (19 June 2012), http://www.g20.utoronto.ca/2012/2012-0619-loscabos.html (accessed 1 Dec. 2019).

17 OECD, Public Consultation Document Pillar 2, supra n. 1, at 30.

18 OECD, Public Consultation Document Pillar 2, supra n. 1, at 6.

19 OECD, Programme of Work, supra n. 2, at 27-28. 
would not be applicable to the four components in the proposal. It would be complex because each subsidiary in an MNE would need to recalculate its income following the tax base rules in the ultimate parent jurisdiction ${ }^{20}$ for the purposes of the income inclusion and the switch-over rules. It would not be applicable to the four components of the proposal because it would provide primacy to the shareholder's jurisdiction, and the undertaxed payments and the subject to tax rules are to be applied by the subsidiary's jurisdiction.

Moreover, referring to the ultimate parent company domestic tax base rules, would not lead to coordinated minimum tax rates, and it would not be neutral in terms of residence versus source or market jurisdictions. The proposal intends to neutrally determine effective tax rates at an international level while not giving primacy to any of the aforementioned types of jurisdictions.

However, it would seem unfeasible to coordinate rates without coordination of tax bases internationally. In order to surmount that obstacle, the GloBE proposes coordination of financial accounting rules: an acceptable and standard set of financial accounting standards or generally accepted accounting principles (GAAP), such as the International Financial Reporting Standards (IFRS), to be employed by the ultimate parent company to prepare its consolidated financial accounts. If this solution is adopted, the definition of a consolidated group would have to align with the definition under BEPS so that only one consolidated account is valid for international tax purposes.

The tax base would then be computed according to those GAAP. The GAAP, applicable at least to listed companies, would also have to be adjusted in order to take into account a number of permanent and temporary differences between the financial account standard and the tax base on the recognition of income and expenses. ${ }^{21}$ Whereas the financial accounts include all income and expenses, tax rules may exclude some income and some expenses; permanently in some cases and temporarily in others. $^{22}$

Adoption of the GAAP to be utilized by the ultimate parent company to prepare its consolidated financial accounts is a beneficial and uncomplicated solution according to the perspective of the internal logic of the GloBE Proposal and taking into account the already existing obligations under Country-by-Country Reporting. The GAAP will allow all involved jurisdictions to check the application of the minimum effective tax rates.

\section{Precedence and neutrality}

One of the main political discussions raised by the proposal concerns the precedence that is applicable to the four measures. This is valid both in respect of precedence among the four measures in Pillar Two and regarding the precedence between them and those that are adopted in the context of the BEPS Project.

As previously mentioned, the income inclusion rule is applicable by the residence jurisdiction. It must be coordinated with the switch-over rule under the proposal in Pillar Two; with the anti-hybrid rules under Action 2; the interest deduction rules under Action 4; the CFC rules under Action 3; and the saving clause under Action $6 .{ }^{23} \mathrm{It}$ must be further coordinated with the undertaxed payments rule and the subject to tax rule that are applicable by the source jurisdiction according to the proposal in Pillar Two.

The precedence issue raised above affects the application of the undertaxed payments rule and the subject to tax rule by the source jurisdiction. The hierarchy in terms of precedence of the undertaxed payments rule must be determined in respect of the subject to tax rule in the proposal, the anti-hybrids rule under Action 2, and also in reference to the income inclusion rule and the switch-over rule.

Whereas the precedence among all measures to be applicable by the residence State, on the one side, and among all measures to be applicable by the source State, on the other, are related to their full effectiveness and internal consistency; the precedence between source and residence is a political issue and has only been raised by Pillar Two (not explicitly under BEPS).

In fact, the precedence of the source State in respect of the anti-hybrid rules was clear in the BEPS Project, however, apart from Action 2 and from the meaning of value creation, priority was given to the residence State by the use of CFC rules and the subject-to-tax rule under the MLI.

The four components in the Pillar Two Proposal announce a deadlock that will incite strong political contention in the international setting. In the absence of a precedence rule - which is likely to be the case - the deadlock will be on the taxpayer and cause international double taxation.

\section{Notes}

20 OECD, Public Consultation Document Pillar 2, supra n. 1, at 9.

21 OECD, Public Consultation Document Pillar 2, supra n. 1, at 10 et seq.

22 OECD, Public Consultation Document Pillar 2, supra n. 1.

23 OECD, Preventing the Granting of Treaty Benefits in Inappropriate Circumstances: Action 6-2015 Final Report, OECD/G20 Base Erosion and Profit Shifting Project 86-88 (OECD Publishing Oct. 2015). 


\section{Blending}

It is to be decided whether determination of the effective tax rate is to be achieved on a worldwide, jurisdictional, or entity blending approach. A worldwide blending (full blending of all foreign income) would lead to a global treatment of incoming dividends and gains in the parent company jurisdiction independently of the entities and jurisdictions that are involved. This would reduce the MNE's compliance costs but would not achieve the purpose underlying the 'minimum tax rate'. It would still allow a significant level of tax competition and foster tax planning by acknowledging a mix of low and high-tax income across different entities and jurisdictions. ${ }^{24}$

In turn, the jurisdictional blending approach would require apportionment of foreign income according to different tax jurisdictions. Additionally, the entity blending approach would require determination of income and taxes in respect of each group entity. The jurisdictional blending and the entity blending approaches will more appropriately correspond to the spirit of Pillar Two.

Jurisdictional blending will contribute to a reduction of tax competition without fully eliminating the possibility to adopt different tax rates in one single jurisdiction as the average effective tax rate in a specific jurisdiction will be calculated. Moreover, it is a less complicated solution than the entity blending approach also in terms of compliance costs, and it is more neutral because it does not differentiate between single taxpayers and merged entities or entities submitted to domestic group regimes.

The entity blending approach is more focused on the taxpayer and, therefore, more focused in contradicting tax planning. The entity's blending approach would bring higher compliance costs.

Other elements of complexity are not mentioned in the proposal. For example, in the event that subsidiaries are submitted to other income taxes in a specific jurisdiction, they also need to be taken into account in the calculation of the effective tax rate. This is not mentioned in the examples illustrating the application of the carry-forward of excess taxes and tax attributes nor for deferred tax accounting for the purposes of potential application of the income inclusion rule. ${ }^{25}$

\section{Concluding Remarks}

The BEPS Project measures, most of them applicable in the residence jurisdiction or at least in the jurisdiction where production occurs (according to where Functions, Assets, and Risks (FAR) take place), should be sufficient for combatting aggressive tax planning. They are likely to provoke international double taxation, and yet none of them appear to be sufficient for addressing profit shifting to jurisdictions where profits are subject to no or very low taxation.

Terms such as 'harmful' or 'aggressive' are not included in the proposal of Pillar Two. This is not an issue of naming and shaming non-cooperative jurisdictions. Whether or not tax competition leads to profit shifting, under the GloBE, covered activities will be submitted to the minimum tax rate and proposed measures.

In the absence of a precedence rule, an international tax jurisdiction, and an international tax court, all jurisdictions will be watching one another as well as watching all taxpayers covered under the GloBE.

We are leading towards a globalized Big Mistrust Model. However, jurisdictions are not bound to have corporate income taxes. Is elimination of the latter the next step in tax competition?

Ana Paula Dourado Editor-in-Chief

\section{Notes}

24 OECD, Public Consultation Document Pillar 2, supra n. 1, 54-59, at 17-18.

25 OECD, Public Consultation Document Pillar 2, supra n. 1, Annex A, at 25 et seq. 